\title{
Rural Households Livelihood Strategies and its Impact on Livelihood Outcomes: The Case of Eastern Oromia, Ethiopia
}

\author{
Beyan Ahmed Yuya ${ }^{1}$, Nano Alemu Daba ${ }^{2}$ \\ ${ }^{1}$ School of Agricultural Economics and Agribusiness, Haramaya University, Dire Dawa, Ethiopia \\ ${ }^{2}$ School of Plant Sciences, Haramaya University, Dire Dawa, Ethiopia
}

\begin{abstract}
This study analyzed the factors affecting smallholder farmers decisions to adopt livelihood strategy choices and its impact on rural households' livelihood outcomes in the Meta district, Eastern Ethiopia during the 2016/17 production year. The data used for the study were obtained from 180 randomly selected sample households. Multinomial logit model was employed to analyze the determinants of farmers' decisions to adopt livelihood strategies. The average effect of adoption on households' farm incomes was estimated by using propensity score matching method. The result of the multinomial logistic regression showed that age of the household head, distance from irrigation sources, social status, soil fertility status, education level, distance from Developmental Agents (DAs) office, economical active members, soil fertility status, soil conservation and transportation services were significantly affects households' adoption decision. Impact evaluation results showed that about $12.9,45.2$ and 41.9 percents of the sample households who using crop farming only, crop + livestock farming, and crop + livestock + off/non-farming strategies were non poor, respectively. Similarly, about 9.4, 30 and 19.4 percents of the sample households who using crop farming only, crop + livestock farming and crop + livestock + off/non-farming strategies were food secured, in that order. The estimation results provides a supportive evidence of statistically significant effect of livelihood strategies on rural households livelihood outcomes measured by food security status and poverty status. Therefore, policy makers should give due emphasis to the aforementioned variables to reduce households level food insecurity status and improve the livelihood of rural households.
\end{abstract}

\section{Keywords}

Households, livelihood strategies, outcomes and multinomial logit model.

Yuya, B. A. and Daba, N. A. (2018) "Rural Households Livelihood Strategies and its Impact on Livelihood Outcomes: The Case of Eastern Oromia, Ethiopia", AGRIS on-line Papers in Economics and Informatics, Vol. 10, No. 2, pp. 93-103. ISSN 1804-1930. DOI 10.7160/aol.2018.100209.

\section{Introduction}

Ethiopia is one of the Sub-Saharan African countries which liberalize its economy to maintain in all sectors to sustained economic growth and reduce poverty. However, five years later this was declining to $29.6 \%$. Moreover, poverty head count is still more prevalent in rural (30.4 percent) than urban areas (25.7 percent) in Ethiopia (CSA, 2015). In Ethiopia, about $83.9 \%$ of total population are live in rural area and agriculture is main source of their livelihood. Since 2010, agriculture becomes the second most dominant next to service sector of the country's economy by providing employment for $80 \%$ of the total labors force and contributes $42.7 \%$ to Gross Domestic Product and 70 percent of foreign exchange earnings (NBE, 2013; CSA, 2013).
Rising the agricultural production at the national level leads to improve overall economic growth and development. However, currently climate change has become a serious threat to sustainable economic growth (Gebreegziabher et al., 2012). Disturbance like drought, eviction, climate change will affect livelihoods and will push households to both farm and nonfarm activities (Baird et al., 2009; Chilongo, 2014). Baird et al. (2013) study revealed that eviction plays a role in shaping diversification strategies in the developing world.

As depicted by FAO (2012), despite agricultural contribution to the livelihood of the society, the increasing population growth in developing countries, including Ethiopia forced households to cultivate and make their living on the small size of land. Due to the decline in land holding 
per individuals as well as fragmentation of their holding and low income obtained from farming activity, the majority of rural households are exposed to food insecurity and chronic poverty. In addition, due to periodic drought and extremely variable environment, making farming risky economic activity farmers face fluctuation in their income. As for Amsalu et al. (2014) finding, rural households diversify their activities into off-farm and nonfarm activities to off-set the diverse forms of risks and uncertainties associated with agriculture; create a way of smoothing their income over the years and seasons; and reduce their vulnerability to different kinds of shocks, seasonality and trends.

The severity of rural livelihood and poverty in developing countries like Ethiopia has necessarily informed a drift in her agricultural systems from the strengthening of national research systems towards systems that enable innovations from individuals and communities, proper transfer and utilization of knowledge and overall transformation. Agricultural productivity remained low as a result not only lack of appropriate technologies and lack of access to those technologies, inputs, credit and access to markets and rural infrastructure, but also because of gaps in information and skills that prevented rural producers from effectively utilizing and adopting technologies (Sanginga et al., 2009). Therefore, the role of agricultural productivity in poverty reduction, improving livelihood and enhancing productivity outcomes cannot be over emphasized. Agricultural productivity and improved livelihood remained low as a result not only of the lack of appropriate technologies and the lack of access to those technologies, inputs, credit and access to markets and rural infrastructure, but also because of gaps in information and skills that prevented rural producers from effectively utilizing and adopting technologies (Miriam et al., 2011).

Livelihoods strategies cannot be identified by a single activity variable only, as the diverse mix of assets available to individual households typically produce a wide range of different asset allocation choices (Barrett et al., 2001). For example, two households endowed with equal areas of land might choose to use that land differently depending on other factors such as human and financial capital at their disposition. Hence, livelihood strategy identification requires clustering a vector of activity variables (e.g., Brown et al., 2006; vanden Berg, 2009), which requires starting with pre-determining a more-or-less arbitrary number of cluster centers. Therefore, this study uses the latent class clustering technique in livelihood strategy identification, which involves a less arbitrary cluster selection technique based on parameter estimation and model testing. The overall objective of this article is to contribute to the understanding of empirical regularities of important sources of income among rural livelihood strategies in developing countries and the factors associated with choice of strategies.

Therefore, enhancement of agricultural productivity is thus an important condition for alleviating rural poverty, and due to it increases household income and stimulating the growth of non-farm activities among rural households. It is widely argued that, achieving agricultural productivity growth will not be possible without developing and disseminating improved agricultural technologies that can increase productivity to smallholder agriculture farm (Asfaw et al., 2012). Like in many other Sub-Saharan African countries, agriculture is the most important sector for economic growth and for the enhancement of household income in Ethiopia. However, lack of adequate farm management practices and low level of inputs applied, the highly rain fed dependent agriculture system are major challenges to sustain the agricultural production in Ethiopia (Pender and Gebremedhin, 2007; Kassie et al., 2009). Despite the fact that, the agriculture sector is mostly susceptible in seasonal rain fall, the rural households are generating their family income from difference sources to averse the risk associated in agricultural farm sector. As a result the main source of income in most rural household of Ethiopia is derived from farm and non-farm activities.

Agriculture is the primary source of rural income as $80 \%$ percent of the rural labor force is engaged in this sector (CSA, 2013). Non-farm income of the rural household referred to an income that the rural households generate from none of crop or livestock production during a one year of agriculture production period. Non-agricultural activities are not getting prevalence in rural Ethiopia because households are rarely practicing dominated by a subsistence agriculture sector. As a result of this, the income from nonfarm activity is also very low. This subsistence agriculture and low level of rural household income is socially and economically could make unstable the rural society. Therefore, it is significantly important to identify the factors that affect agricultural productivity and find the methods of the rural household income improvements. 
Rural households in the study area engage in diverse livelihood strategies away from purely crop and livestock production towards nonfarm and off-farm activities which are undertaken to generate additional income for survival and cope with harsh conditions. But, there was no empirical data that substantiate or supports the existing livelihood strategies practiced by the farmers in the study area. To intervene the problem, there needs to untie the interwoven factors which can motivate rural households to diversify their livelihood strategies and improve their participation in different off -farm and /or non-farm activities have got paramount importance to development practitioners and policy makers to find the way out (Gebrehiwot and Fekadu, 2012). Therefore, a thorough understanding of factors determining choice of livelihood strategies is important to improve the response mechanisms related to poverty, food security and livelihood improvement. Hence, this study aimed at investigating the livelihood strategies practiced by rural households and its impact on livelihood outcomes. This study was focused on rural households' livelihood strategies and its impact on households' livelihood outcomes at the farm household level in eastern Ethiopia at large and in Meta district of eastern Hararghe zone in particular. The objective of the study was, therefore, to identify the determinants of rural households' choice of livelihood strategies and its contribution in improving rural livelihood outcomes in Meta of Oromia, eastern Ethiopia.

\section{Materials and methods}

\section{Description of the study area}

The study was conducted in Meta district among 19 districts of eastern Hararghe zone of Oromia regional state. Based on statistical figures published by the Central Statistical Agency (CSA) in 2015, this district has an estimated total population of 240,285 of whom 117,864 are men and 122,421 are women; 12,459 or $5.19 \%$ of its population are urban dwellers, which is less than the Zonal average of $6.9 \%$. Meta has an estimated population density of 365.7 people per square kilometer, which is greater than the Zone average of 102.6. In general, the district is designated as famine prone and frequent crop failure is a common problem usually leading to food shortage. Drought induced food insecurity has been a common recurrent phenomena exacerbating the vulnerability of resource poor farm households in the area to be food insecure (MARDO, 2013). The land use pattern of Meta district consists $48 \%$ arable and $13 \%$ pasture and forest, and the rest $39 \%$ regarded as degraded (CSA, 2013). Sorghum, maize, barley and wheat are the major food crops in the district, whereas khat and coffee are the major cash crops. The farming system of the administration consists of crop production (4.1\%), livestock production (7.9\%) and householders that are engaged in mixed crop and livestock production $(88.0 \%)$.

\section{Sources of data and methods of data collection}

As sources of information both primary and secondary data sources were used. The primary data were collected by the trained enumerators. In addition to primary data, secondary data were also collected from relevant sources such as published and unpublished documents from the relevant institutions for general description and to augment primary data.

\section{Sample size and sampling technique}

Meta district was selected purposively due its potential area for cereal crops and problems of rural households livelihoods. From this district two peasant associations were selected purposively because of their accessibility. Then the sample from each peasant association selected randomly based on probability proportion to size. Finally, a total of 180 sample respondents were interviewed.

\section{Methods of data analysis}

To address the objective of the study, both preliminary statistics and econometric methods were employed. Mean comparison was employed for impact evaluation and Multinomial logit was used to identify determinants of smallholder farmers decision to choice livelihood strategies

\section{Food security measure}

Food security pillars: Access, availability, utilization and stability are frequently cited in the literatures as organizing principles for food security measurement (Jones et al., 2013; Carletto et al., 2013; Coates, 2013). However, many authors note that the "pillars" analogy can hamstring improved food security measurement efforts because each one has not been welldefined (Berry, 2015; Coates, 2013; Moltedo et al., 2014). Household surveys yield information about household expenditure decisions and take the actual demographic structure of the household into account (de Haen, 2011). They are also costly to implement and tend to be infrequently administered (Jones et al., 2013; de Haen, 2011). 
Perhaps recent research suggests household food consumption expenditure results can vary significantly based on survey design, with some authors arguing this should be only be used with great caution until more consistent and comparable survey data collection can be completed (de Weerdt et al., 2015; Carletto et al., 2013). Therefore, in this study household food expenditure was used. In this measure the frequency of dietary food consumption of different food groups consumed by a household during the last 7 days before the survey was calculated and consumption score is then calculated using weights assigned to each food group using the cut-off point of 2200 kilocalories as the minimum caloric requirement, used by official reports in Ethiopia (MOFED, 2010).

\section{Construction of poverty indexes}

Based on poverty line, three poverty measures that were identified by Foster et al. (1984) were employed. The headcount index indicates the proportion of population regarded as poor. The headcount index was estimated as:

Headcount Index $(H C)=\frac{P}{n}$

Where, $P=$ the number of poor people; $n=$ population size.

On the other hand, poverty gap index was calculated as following. to determine the poor below the poverty line on average. If $Z$ is a poverty line, $Y_{i}$ is the per capita income of $i$, then the poverty gap is

$$
\text { Poverty Gap }(P G)=1 / n \sum_{1-i}^{n}\left[\frac{z-y_{i}}{z}\right]
$$

Where, $Z=$ poverty line; $Y_{i}=$ the per capita of $i$. In the equation, $z-y_{i}=0$ if $y_{i}>z$.

Squared poverty gap measures the severity of poverty giving more weight to the poor and was depicted as follows.

Squared poverty $\operatorname{gap}(G P)^{2}=1 / n \sum_{i=i}^{n}\left(\frac{z-y_{i}}{z}\right)^{2}$

All the above three measures, which depend on parameter, is given below.

$p_{(\alpha)}=1 / n \sum_{1-i}^{q}\left(\frac{-y_{i}}{z}\right)^{\alpha}$
Where $\alpha$ takes a value of zero for the headcount index, one for the poverty gap index and two for the squared poverty gap index

7. Determinants of the choice of livelihood strategies

\section{Multinomial Logit (MNL)}

The MNL model was used by many researchers to the model determinants of households' choices of livelihood strategies in the context of multiple choices (Deressa et al., 2019, Nhemachena and Hassan, 2008). To describe the multinomial logit model, let $Y i$ denoted vector of options for strategies to chosen by farmer household. This model for a livelihood choice specifies the following relationship between the probability of choosing option and the set of explanatory variables $X i$ as (Greene, 2003)

$$
\operatorname{Pr} o b(y i=j)=\frac{e^{\beta j i x i}}{\sum_{k=0}^{j} e^{\beta / x i}}
$$

Equation (6) was normalized to remove indeterminacy in the model by assuming $\beta_{0}=0$ and the probabilities were estimated as:

$$
\begin{aligned}
\operatorname{Pr} o b(y i=j / x i)=\frac{e^{\beta j x i}}{1+\sum_{k=0}^{j} e^{\beta k x i}} \\
\quad j=0,1,2 \ldots j, \beta_{0}=0
\end{aligned}
$$

Where, $j$ stands for livelihood strategies, $x$ stands for explanatory variables and $\beta^{\prime \prime}$ stands for parameters to be estimated. The estimated parameter of the MNL model provide only the direction of the effect of the explanatory variables on the dependent variable (livelihood strategies), but do not represent either the actual magnitude of change or probabilities. To interpret the effects of explanatory variables on the probabilities, marginal effects are usually derived as indicated by Greene (2003). Maximum likelihood estimation of equation (8) yielded the log-odds ratio. The dependent variables of any adaptation option is therefore the $\log$ of odd in relation to the base alternative.

$\ln \left(\frac{p i j}{p i k}\right)=x i(\beta j-\beta k)=x i \beta j, \quad$ if $k=0$

According to Greene (2003), the MNL coefficients are difficult to interpret and associating with the $j^{\text {th }}$ outcome is tempting and misleading. Marginal effect is useful to interpret the effect of independent variable on the dependent variable in terms of probabilities. 


$$
\frac{\partial p j}{\partial x i}=p j\left(\beta j-\sum_{k=0}^{j} p k \beta j\right)=p j(\beta i-\beta)
$$

\section{Results and discussion}

\section{Descriptive statistical results for continuous variables}

The results of the study showed that, the mean age of household age was 36 years and the mean household size and economical active members were 5 and 2.98 in person and men equivalent, respectively (Table 1). Similarly, the mean cultivated land and livestock holding were 0.397 and 3.55 in hectare and tropical livestock unit, in that order. Likewise, the descriptive result indicated that the total crop output and livestock income were 1474.23 and 4399.27 in quintals and birr, respectively. The results of infrastructural distances from the residence indicated that, on average there were about 10.5, 24.3, 26.7 and 88 meter distances in terms of irrigation sources, DA office and weather road in munities, respectively.

2. Descriptive statistical results for dummy variables

The results of the study revealed that, on average about 90, 68.89, 65 percents of the sample households were male, participated in soil conservation and farmers training, respectively. Similarly, about 36.11 and 66.11 percents of the sample farmers were participated in social status and had fertile cultivated land, respectively. Whereas, about 22, 64 and 13 percents of the sample farmers used human force, pack animals and vehicles for transportation of their farm inputs and out puts, respectively (Table 2).

\begin{tabular}{lcc}
\hline Sex & Freq. & Percent \\
\hline Female & 18 & 10.00 \\
Male & 162 & 90.00 \\
Total & 180 & 100.00 \\
Soil conservation & Freq. & Percent \\
not & 56 & 31.11 \\
conserved & 124 & 68.89 \\
Total & 180 & 100 \\
Farmer training & Freq. & Percent \\
Otherwise & 63 & 35.00 \\
Participated & 117 & 65.00 \\
Total & 180 & 100 \\
Transportation & Freq. & Percent \\
human labor & 40 & 22.22 \\
pack animals & 116 & 64.44 \\
Vehicles & 24 & 13.33 \\
Total & 180 & 100.00 \\
Social status & Freq. & Percent \\
Not & 115 & 63.89 \\
Participated & 65 & 36.11 \\
Total & 180 & 100.00 \\
Soil fertility status & Freq. & Percent \\
otherwise & 61 & 33.89 \\
fertile & 119 & 66.11 \\
Total & 180 & 100.00 \\
\hline & & \\
\hline & &
\end{tabular}

Source: own survey, 2017

Table 2: Descriptive results for dummy variables.

\section{Determinants of farmers' choice of livelihood strategies}

Multinomial logit model was used to identify the determinants of rural households' choice of livelihood strategies (Table 3). The model analysis used relying on farm alone as the base

\begin{tabular}{lcccc}
\hline Variable & Mean & Std. Dev. & Min & Max \\
\hline Age in years & 35.72778 & 7.439762 & 19 & 71 \\
Education in grade & 2.583333 & 3.659952 & 0 & 12 \\
Family size in number & 5.827778 & 1.703859 & 1 & 9 \\
Economic active & 2.985 & 1.018761 & .8 & 6.15 \\
\hline Cultivated area in hector & .3975694 & .5414781 & .0625 & 5 \\
Crops output in quintal & 1474.239 & 2511.319 & 240 & 30000 \\
Livestock income in birr & 4399.272 & 3873.179 & 0 & 8.949 \\
Livestock holding in TLU & 3.546433 & 2.325793 & 0 & 50 \\
\hline Irrigation distance in minute & 24.33333 & 11.54684 & 2 & 60 \\
DA office distance in minute & 26.71667 & 13.33424 & 2 & 180 \\
W/road distance in minute & 88.25 & 30.96888 & 30 & \\
\hline Source: own survey, 2017 & & & & 5 \\
\hline
\end{tabular}

Source: own survey, 2017 
category for no diversification and evaluates the other choices as alternatives to this option. The overall model is significant at $1 \%$. Therefore, in this study, only those variables, whose coefficients were statistically significant at less than or equal to $10 \%$ level of significance were discussed. Age of the household head, distance from irrigation sources, social status, soil fertility status, education level, distance from DA office, Economical Active members, soil fertility status, soil conservation and transportation services used were statistically significant variables that determining rural household's choice of livelihood strategies in the study area.

- Age of household head: It affected farmers' decision to diversify livelihood strategy positively and significantly at $5 \%$ (Table 3). Holding other variables constant, the likelihood of household head to choice crop farming strategy increases by 0.05 units, when age increase by one year relative to the base category is relying on farm and livestock farming. The possible reason is that elder farmers are well established and more experienced in agricultural production, more resistant to new ideas and information and they are more likely to be set in their ways and may not venture into new diversification activities, as also revealed by other study (Fikru, 2008).

- Education level: It was found to have a positive and significant effect on the use of farm plus off-farm strategies at 5\% significance level (Table 3). Ceteris paribus, one extra grade in the household education increases the likelihood of using farm plus off/non-farm strategies by 0.248 units. This could be due to the relation between farmers education in order to meet basic needs of the family relative to the benchmark alternative farm alone. Furthermore, educated families are able to practice multiple activities, whereas uneducated ones tend to practice only crop production activity. This current finding is in agreement with previous observation (Bezemer and Lerman, 2002).

- Total agricultural outputs: As expected, this variable found to have a positive and significant influence on household's choice of on-farm plus non-farm, and a combination of on-farm and off/nonfarm livelihood diversification strategies at less than $10 \%$ level of significance (Table 3). From the model result, other things being constant, the marginal effect reveals that the probability of a household using on-farm plus non-farm and combination of on farm and off/non-farm activities increased by 0.00043 unit. For those farm households output increased by one quintal. This is because households with large total output can easily meet their consumption as well as other family requirements and beyond that they go for demand pull livelihood outcomes (such as accumulation of assets, more income, etc.). Thus, they can easily overcome financial constraints to engage in alternative non/off-farm activities. Also, Yizengaw et al. (2015) found a positive and significant on this variable .

- Soil fertility status: It positively and significantly influenced the use of crop farm and on farm plus non/off-farm livelihood strategies at 5\% significance level (Table 3). That means, Ceteris paribus, being the farm households soil fertility status fertile, the probability of the households using crop farming and on farm plus off/non farming strategies increases by 1.08 and 2.19 units, respectively. This is explained by the fact that fertile land is a proxy for wealth status of farmers. Those farmers with fertile land can easily meet their family food and other requirements and have a better chance to earn more money to invest in non-farm income generating activities with an intention of accumulating assets for the future. This result is inconsistent with the findings of Amare and Belaineh (2012).

- Developmental Agent (DA) office distance: It has a negative and significant impact on diversification of livelihood strategies at $5 \%$ significance level (Table 3). From the model result, other things being constant, the probability of a household using on-farm plus off/non-farm activities decreased by 0.06 units as DA office distance increases by one minutes. The possible justification is that extension services are an important source of information on agronomic practices. The availability of better agricultural information and technical assistance on agricultural activities helps farmers to produce alternative crops; and to obtain higher production and income. Similar observations were also reported by other researchers (Seid et al., 2016). 
- Soil conservation: It has a negative and significant impact on livelihood of using the crop farming activities only at 5\% significance level (Table 3). From model result, other things being constant, the use of soil conservation decreases the probability of a household using on farm activities by 1.048 units. This is because farmers use conservation technologies to improve their agricultural production and productivity. These in turn help them to satisfy family consumption requirements and improve their income rather than using a combination of on-farm and non-farm activities.

- Membership to social status: As expected, this variable found to have a negative and significant influence on household's choice of only crop farming strategy at less than 5\% level of significance (Table 3 ). The coefficient reveals that, holding other things constant, being a member of social status decreases the probability of a household using only crop farming strategy by 1.42 units. This is because a social capital that promotes sharing of knowledge, information, experience, etc., regarding the value of off and non- farm activities that helps them to improve their livelihood.
In addition, cooperatives serve as a means of gaining off-farm and non- farm employment opportunities. This finding is inconsistent with the findings of Adugna and Wagayehu (2012).

- Economical active members: It is found to have a positive and significant effect on the combined use of on-farm and non/off farm as a livelihood strategy at 5\% significance level as compared with relying only on-farm activities to drive their livelihood. The marginal effect reveals that, holding other things constant, having one more active member increases the livelihood of a household using combination of on-farm and non/off-farm activities by 0.164 units. This is because most of the economical active farmers were on ways of improving agricultural production and productivity. This in turn helps them to get better production, and then this most likely leads to obtain more income to fulfill their family requirements by enhancing their agricultural production skills, knowledge and experiences. The result of the study is inconsistent with the findings of Yishak et al. (2014).

\begin{tabular}{|c|c|c|c|c|c|c|}
\hline \multirow[b]{2}{*}{ Variables } & \multicolumn{3}{|c|}{ Crop framing only } & \multicolumn{3}{|c|}{ Crops, livestock and off/non farming users } \\
\hline & Coefficients & Std.error & $\mathrm{p}>\mathrm{z}$ & Coefficients & Std.error & $\mathrm{p}>\mathrm{z}$ \\
\hline Age & $.0532166^{*}$ & .0284842 & 0.062 & .0294265 & .044793 & 0.511 \\
\hline Education & .0516751 & .0676691 & 0.445 & $.2483477 * *$ & .0971032 & 0.011 \\
\hline DA distance & .0138037 & .0165707 & 0.405 & $-.0603002 * *$ & .023963 & 0.012 \\
\hline Eco Active & -.1113461 & .2619369 & 0.671 & $.614172 * *$ & .3124958 & 0.049 \\
\hline Cultivated & .0839905 & .3433125 & 0.807 & .0676469 & .4345916 & 0.876 \\
\hline Soil conservation & $-1.048595 * *$ & .4737368 & 0.027 & -.5460457 & .6281843 & 0.385 \\
\hline Livestock & -.0000624 & .0000738 & 0.398 & .000054 & .0000719 & 0.453 \\
\hline Crop output & -.0001857 & .0002977 & 0.533 & $.0001437 *$ & .0000774 & 0.064 \\
\hline Irrigation distanc & $.0743335 * * *$ & .0234058 & 0.001 & -.0130695 & .0381273 & 0.732 \\
\hline Farmer training & -.4355286 & .4814686 & 0.366 & 1.728082 & 1.107863 & 0.119 \\
\hline Transportation & .1484154 & .2707957 & 0.584 & $.610888 * *$ & .2994302 & 0.041 \\
\hline Social status & $-1.420355^{* *}$ & .5093427 & 0.005 & .0863504 & .5732678 & 0.880 \\
\hline Soil fertility & $1.082839 * *$ & .5397402 & 0.045 & $2.193368 * *$ & 1.110765 & 0.048 \\
\hline Weather $\mathrm{R}$ dista & -.0122553 & .0085411 & 0.151 & -.0180528 & .0141641 & 0.202 \\
\hline constant & -2.909335 & 1.853647 & 0.117 & $-4.390809 *$ & 2.635288 & 0.096 \\
\hline \multicolumn{4}{|c|}{ Number of obs $=180 \quad \operatorname{LR}_{\operatorname{chi}^{2}}(28)=129.13$} & & & \\
\hline \multicolumn{4}{|c|}{ Prob $>$ chi $^{2}=0.0000$} & & & \\
\hline \multicolumn{4}{|c|}{ Log likelihood $=-124.29825 \quad$ Pseudo $\mathrm{R}^{2}=0.3419$} & & & \\
\hline
\end{tabular}

Note: $* * *, * * *$ means significant at $1 \%, 5 \%$ and $10 \%$ percent level of significance

Sources: own survey result, 2017

Table 3. Multinomial logit result for determinants of livelihood strategy choices. 
- Means of transportation: the model result showed that transportation positively and significantly affected using a combination of on-farm and non/off-farm activities as a livelihood strategy at $5 \%$ significance level as compared with the base category (Table 3). The marginal effect of the model reveals that, holding other things constant, using pack animals transportation in agricultural production increases the livelihood of a household using a combination of on-farm and non-farm activities by 0.611 units. The possible reason could be better transportation most likely increase the production and productivity of crops produced by the farmer, and this can help a farmer to get access to more food and generate more income so that they satisfy their family requirements. In conformity with the current result, Woinishet (2010) reported that transportation positively and significantly affected using the combination of on-farm and non/off-farm activities as a livelihood strategy.

\section{Impacts of livelihood strategies on rural livelihood outcomes}

This section provides evidence as to whether or not the choices of livelihood strategies have brought significant changes on rural livelihood outcomes. Accordingly, the estimation result provides a supportive evidence of statistically significant effect of livelihood choice on rural households livelihood outcomes measured by food security and poverty status (Tables 4 and 5). After controlling for pre-participation differences in demographic, location and asset endowment characteristics of the user and non- user households, it has been found that, on average, about $12.9,45.2$ and 41.9 percents of the sample households who using crop farming only, crop and livestock farming and crop + livestock and off/non farming strategies were non poor respectively. The chi square test results showed there were statistically significant mean differences among these groups at 1 percent significant level (Table 4).

The survey result also indicated that, on average; about 9.4, 30 and 19.4 percents of the sample households who using crop farming only, crop + livestock farming and crop + livestock + off/non farming strategies were food secured, respectively (Table 5).

The chi square test results showed were statistically significant mean differences among these groups at 1 percent significant level (Table 5).

\begin{tabular}{|c|c|c|c|c|c|c|c|c|c|c|}
\hline \multirow[t]{3}{*}{ Variable } & & \multicolumn{9}{|c|}{ Livelihood strategies } \\
\hline & & \multicolumn{2}{|c|}{ Crop farming only } & \multicolumn{2}{|c|}{ Crop + Livestock } & \multicolumn{2}{|c|}{$\begin{array}{c}\text { Crop + Livestock } \\
+ \text { off/non-farm }\end{array}$} & \multicolumn{2}{|c|}{ Total } & \multirow[t]{2}{*}{$\mathrm{Chi}^{2}$} \\
\hline & & Numb & $\%$ & Numb & $\%$ & Numb & $\%$ & Numb & $\%$ & \\
\hline \multirow{3}{*}{$\begin{array}{l}\text { Poverty } \\
\text { Status }\end{array}$} & Non-poor & 12 & 6.7 & 42 & 23.3 & 39 & 21.7 & 93 & 51.7 & \\
\hline & Poor & 38 & 21.1 & 45 & 25 & 4 & 2.2 & 87 & 48.3 & $41.958 * * *$ \\
\hline & Total & 50 & 27.8 & 87 & 48.3 & 43 & 23.9 & 180 & 100 & \\
\hline
\end{tabular}

Note: $* * *$ means significant at 1 percent level of significance

Sources: own survey result, 2017

Table 4: Impacts of livelihood strategies on household level poverty status.

\begin{tabular}{|c|c|c|c|c|c|c|c|c|c|c|}
\hline \multirow{3}{*}{\multicolumn{2}{|c|}{ Variable }} & \multicolumn{9}{|c|}{ Livelihood strategies } \\
\hline & & \multicolumn{2}{|c|}{ Crop farming only } & \multicolumn{2}{|c|}{ Crop + Livestock } & \multicolumn{2}{|c|}{$\begin{array}{l}\text { Crop + Livestock } \\
+ \text { off/non-farm }\end{array}$} & \multicolumn{2}{|c|}{ Total } & \multirow[t]{2}{*}{$\mathrm{Chi}^{2}$} \\
\hline & & Numb & $\%$ & Numb & $\%$ & Numb & $\%$ & Numb & $\%$ & \\
\hline \multirow{3}{*}{$\begin{array}{l}\text { Food } \\
\text { Security } \\
\text { Status }\end{array}$} & Not sec & 33 & 18.3 & 33 & 18.3 & 8 & 4.4 & 74 & 41.1 & \\
\hline & Secured & 17 & 9.4 & 54 & 30 & 35 & 19.4 & 106 & 58.9 & $22.15^{* * *}$ \\
\hline & Total & 50 & 27.8 & 87 & 48.3 & 43 & 23.9 & 180 & 100 & \\
\hline
\end{tabular}

Note: $* * *$ means significant at 1 percent level of significance

Sources: own survey result, 2017

Table 5: Impacts of livelihood strategies on household level food security status. 


\section{Conclusion}

Increasing rural livelihoods through investment in sustainable agricultural practices and off/non farming activities are important for the reduction of hunger and poverty in Ethiopia. In this study, we analyzed the factors determine probability of livelihood choices and its contributions to rural households livelihood outcomes by smallholder farmers in east Oromia, Ethiopia using farm household level observations. The data were collected from 180 sample household in 2016/17 cropping year. Multinomial logit model is used to identify the factors that determine the probability of the choices of livelihood strategies and mean comparison was used for impact evaluations.

The Multinomial result indicated that; age of HH head, distance from irrigation sources, social status, soil fertility status, education level, distance from DA office, Economical Active members and soil fertility status, transportation and annual agricultural output were significant variables determining household's choice of livelihood strategies.

The estimation result provides a supportive

Corresponding authors:

Nano Alemu Daba

School of Plant Sciences, Haramaya University. P. O. box 95, Dire Dawa, Ethiopia

E-mail: nanoalemu2001@gmail.com

\section{References}

[1] Adugna, E. and Wagayehu, B. (2012) "Determinants of livelihood strategies in Wolaita, southern Ethiopia", Agricultural Research and Reviews, Vol. 1, No. 5, pp. 153 -161.

[2] Amare, D. and Belaineh, L. (2013) "Determinants of income diversification among rural households: The case of smallholder farmers in Fedis district, Eastern Hararghe zone, Ethiopia", Journal of Development and Agricultural Economics, Vol. 5, No. 3, pp. 120-128. DOI 10.5897/JDAE12.104.

[3] Amsalu, B., Kindie, G., Belay, K. and Chaurasia, S. P. R. (2014) "The role of rural labor market in reducing poverty in Western Ethiopia", Journal of Development and Agricultural Economics, Vol. 6, No.7, pp. 299-308. DOI 10.5897/JDAE2013.0518.

[4] Asfaw, S., Shiferaw, B., Simtowe, F. and Lipper, L. (2012) "Impact of Modern Agricultural Technologies on Smallholder Welfare, Evidence from Tanzania and Ethiopia", Food policy, Vol. 37, pp. 283-295. ISSN 0306-9192. DOI 10.1016/j.foodpol.2012.02.013

[5] Barrett, C. B., Reardon, T., and Webb, P. (2001) "Nonfarm income diversification and household livelihood strategies in rural Africa: concepts, dynamics, and policy implications", Food Policy, Vol. 26, No. 4, pp. 315-331. ISSN 0306-9192. DOI 10.1016/S0306-9192(01)00014-8.

[6] Berg, M. V. D. and Kumbi, G. E. (2009) "Poverty and the Rural Non-Farm Economy in Oromia Ethiopia", International Association of Agriculture Economists Conference, Gold Coast Australia. 
[7] Bezemer, D. J. and Lerman, Z. (2002) "Rural Livelihoods in Armenia", The Centre for Agricultural Economic Research, the Department of Agricultural Economics and Management Discussion Paper No. 4.03.

[8] Brown, D., Stephens, E. C., Ouma, J. O., Murithi, F. M. and Barrett, C. B. (2006) "Livelihood strategies in the rural Kenyan highlands", African Journal of Agricultural and Resource Economics, Vol. 1, No. 1, pp. 21-35.

[9] CSA (Central Statistical Agency) (2015) "Household Income, Consumption and Expenditure Survey Report", Addis Ababa, Ethiopia

[10] CSA (Central Statistical Agency) (2013) "Agriculture Sample Survey of Farm Management Practice Report", Addis Ababa, Ethiopia.

[11] Carletto, C., Zezza, A. and Banarjee, R. (2013) "Towards better measurements of household food security, Harmonizing Indicators and the Role of Household Surveys", Global Food Security, Vol. 2, No. 1, pp. 30-40. ISSN 2211-9124. DOI 10.1016/j.gfs.2012.11.006.

[12] Coates, J. (2013) "Build it back better: deconstructing food security for improved measurement and action", Global Food Security, Vol. 2, No. 3, pp. 188-194. ISSN 2211-9124. DOI 10.1016/j.gfs.2013.05.002.

[13] de Haen, H., Klasen, S. and Qaim, M. (2011) "What do we really know? Metrics for food insecurity and under nutrition", Food Policy, Vol. 36, No. 6, pp. 760-769. ISSN 0306-9192. DOI 10.1016/j.foodpol.2011.08.003.

[14] Deressa, T. T., Hassan, R. M., Ringler, C., Alemu, T. and Yusuf, M. (2019) "Determinants of farmers' choice of adaptation methods to climate change in the Nile Basin of Ethiopia", Global Environmental Change, Vol. 19, No. 2, pp. 248-255. ISSN 0959-3780. DOI 10.1016/j.gloenvcha.2009.01.002.

[15] De Weerdt, J., Beegle, K., Friedman, J. and Gibson, J. (2015) "The challenge of measuring hunger", World Bank Development Working Group Policy Working Paper, 6736.

[16] FAO (Food and Agriculture Organization of the United Nations) (2012) "World Food and Agriculture", Statistical Year Book, Rome.

[17] Fikru, T. (2008) "A Case Study of Non-Farm Rural Livelihood Diversification in Lume Woreda, Oromia Reginonal State", A Master of Arts Thesis in Development Studies, Addis Ababa University, Ethiopia.

[18] Gebrehiwot, W. and Fekadu, B. (2012) "Rural household livelihood strategies in drought-prone areas: A case of Gulomekeda District, eastern zone of Tigray, Ethiopia", Journal of Development and Agricultural Economics, Vol. 4, No. 6, pp.158-168. DOI 10.5897/JDAE12.026.

[19] Greene, W. H. (2003) "Econometric analysis", Fifth edition, Prentice Hall, New Jersey.

[20] Gebreegziabher, Z., Mekonnen, A. and Seyoum, A. (2012) "Carbon Markets and Mitigation strategies for Africa/Ethiopia: Literature Review and the way forward", EDRI research report 14.

[21] Hassan, R., and Nhemachena, C. (2008) "Determinants of African Farmers' Strategies for Adapting to Climate Change. Multinomial Choice Analysis". African Journal of Agricultural and Resource Economics. Vol. 2, No. 1.pp. 53-60.

[22] Jones, A. D., Ngure, F. M., Pelto, G. and Young, S. L. (2013) "What Are We Assessing When Measure Food Security? Compendium and Review of Current Metrics", Advances in Nutrition, Vol. 4, No. 5, pp. 481-505. E-ISSN 2156-5376, ISSN 2161-8313. DOI 10.3945/an.113.004119.

[23] Kassie, M., Zikhali, P., Manjur, K. and Edwards, S (2009) "Adoption of sustainable agriculture practices: Evidence from a semi-arid region of Ethiopia", Natural Resources Forum, Vol. 39, pp. 189-98. E-ISSN 1477-8947. DOI 10.1111/j.1477-8947.2009.01224.x. 
[24] Mariam, A. M., Johann, F. K. and Ferdinand. H. M. (2011) "Agricultural rural innovation and improved livelihood outcomes in Africa". [Online]. Available: https://www.researchgate.net/ publication/265408073_Agricultural_rural_innovation_and_improved_livelihood_outcomes_in_ Africa \{Accessed: Feb. 15, 2018].

[25] MoFED (Ministry of Finance and Economic Development, Ethiopia) (2010) "Growth and Transformation plan (GTP)", Vol.1, 2010/11-2014/15.

[26] Moltedo, A., Troubat, N., Lokshin, M. and Sajaia, Z. (2014) "Analyzing food security using household survey data: streamlined analysis with ADePT software", World Bank Publications. E-ISBN 978-1-4648-0140-2, ISBN 978-1-4648-0133-4. DOI 10.1596/978-1-4648-0133-4.

[27] NBE (National Bank of Ethiopia) (2013) "Annual Report", Addis Ababa, Ethiopia.

[28] Pender, J. and Gebremedhin, B. (2007) "Determinants of agricultural and land management practices and impacts on crop production and household income in the highlands of Tigray, Ethiopia", Journal of African Economies, Vol. 17, No. 3, pp. 395-450. E-ISSN 1464-3723, ISSN 0963-8024. DOI 10.1093/jae/ejm028.

[29] Sanginga, P. C., Waters-Bayers, A., Kaaria, S., Njuki, J. and Wettasinha, C. (2009) "Innovation Africa: Beyond Rhetoric to Praxis", In: Sanginga, P. C., Waters-Bayers, A., Kaaria, S., Njuki, J., and Wettasinha, C. (eds.) "Innovation Africa: Enriching farmers livelihoods", Earthscan: London, pp. 374-386.

[30] Seid, S., Jema, H. and Degye, G. (2016) "Climate Change Adaptation Strategies of Smallholder Farmers: The Case of Assosa District, Western Ethiopia", Journal of Environment and Earth Science, Vol. 6, No. 7. E-ISSN 2225-0948, ISSN 2224-3216.

[31] Yishak, G., Gezahegn, Tesfaye, L. and Dawit, A. (2014) "Rural household livelihood strategies: Options and determinants in the case of Wolaita Zone, Southern Ethiopia", Journal of Social Sciences, Vol. 3, No. 3, pp. 92-104.

[32] Yizengaw, S. Y., Okoyo, E. N. and Fekadu, B. (2015) "Determinants of livelihood diversification strategies, The case of smallholder rural farm households in Debre Elias Woreda, East Gojjam Zone, Ethiopia", African Journal of Agricultural Research, Vol. 10, No. 19, pp. 1998-2013. ISSN 1991-637X. DOI 10.5897/AJAR2014.9192. 